\title{
A Study on the Plastic Waste and Environmental Degradation
}

\section{Ponnusamy Rajkumar}

Associate Professor, Department of Sociology, Madurai Kamaraj University, Madurai, Tamil Nadu, INDIA

Corresponding Contact:

Email: eswar_rajkumar@yahoo.co.in

Cell Phone: +919894177680

\begin{abstract}
Plastic waste component of the urban solid waste is quite problematic. As it is non-biodegradable, it can stay in the environment for a longer time causing severe environmental degradation. Unless it is properly disposed of, environmental degradation is unavoidable. The environmental degradation would potentially harm the human and biological wealth. The study has made an attempt to understand the extent of usage of plastic materials and the mode of disposal thereof by the people. It is an empirical study based upon the data collected from the Tiruchirappalli City of Tamil Nadu, India. The data collected for the study are from 515 residents of the city who are selected through multistage random sampling method. The first step is, identification of wards (the sub divisions of the Zone of an urban community in India) from the zones of the city and secondly, the identification of households at random. From the selected households, the researcher identified the available senior most adult members as the respondents and by using the tool of interview-schedule, (a tool which is having a set of questions can be employed among literate and illiterate respondents for the collection of primary data) the data collected from them. The disposal pattern of each income group is having association with the attitude towards the disposal and the level of environmental awareness.
\end{abstract}

Keywords: Plastic Wastes, Annual Family Income, Environmental Concern, Attitude, Disposal of Plastic Wastes

$1 / 30 / 2015$ Source of Support: Nil, NO Conflict of Interest: Declared.

How to Cite: Rajkumar P. 2015. A Study on the Plastic Waste and Environmental Degradation. ABC Journal of Advanced Research, 4, 9-16.

This article is is licensed under a Creative Commons Attribution-NonCommercial 4.0 International License. Attribution-NonCommercial (CC BY-NC) license lets others remix, tweak, and build upon work non-commercially, and although the new works must also acknowledge \& be non-commercial.

\section{INTRODUCTION}

Gigantic Multi-storied buildings, pleasant and healthy suburbs, parklands as forests and beautiful wider streets with trees featured Indian cities' environment some years ago. But, the condition in India, today, is contrasting to its previous self. The upward rate of urbanization all over the world has resulted in the creation of mounting amounts of waste and this in turn creates greater complexities for disposal (Heynen, 2003). Strengthened Solid Waste Management is an essential issue for not only the developing countries but 
also for the developed countries. Mammoth of Waste is getting generated all over the world, and the important critical issue is how effectively and efficiently these wastes can be managed for the sustenance of the mankind and the environment. Many urban localities continue to struggle with the trouble of Solid Waste Management and the Corporation of Tiruchirappalli, India is not an exception.

Due to the biodegradability the Organic part of the Municipal Solid Waste may not be a giant issue. But, the Plastic Waste part of the Municipal Solid Wastes is always troublesome due to their non-biodegradability. The Plastic Waste elements can stay for a significant period of time in the environment and causing the entire nuisance. Plastics are petroleum-based products, derived from non-renewable resources. The plastic bag has become an indispensable part of Indian shopping. The plastic shopping bag is resource efficient, cheap, lightweight, moisture resistant, and functional. For its weight it is extraordinarily strong. At supermarkets quick and easy packing is possible with the plastic bags. Even tough, the apparent repercussions of plastic waste have increased the community concern.

India Business (2013) gives a report that in India during 2012-13 the polymer industries' per capita consumption was low $(9.7 \mathrm{~kg}$ ) when compared to USA (109 kg), China (45 kg), and Brazil $(32 \mathrm{~kg})$. Based on a report the Plastic News (2013) says that by 2016-17 the polymers demand will rise up to 16.5 million metric tonnes from 11 million tonnes during 2012-13, ensuing in consumption increase by 10.8 per cent compound annual growth rate. The report expects that India's demand set will arrive at $\$ 24$ billion in packaging by 2016 with which India will be one of the top 10 consumers of packaging at global level. A large amount of plastics that we use are becoming waste in no time. A high percentage of the plastics being produced ends up in litter streams rather quickly and does not serve longterm needs. Most plastics used in India are in the packaging sector. In fact, almost 52 per cent of all plastics is used in packaging (Chintan, 2010).

Due to the depressing repercussions of plastic wastes on environment, the global community has placed a focus on it since they are: generally given more in numbers at free of cost; singleuse and dispose products; resulting in unpleasant visual- and environmental litter impacts due to the non-biodegradability; having chances to be replaced by substitutes and methods; and ignored by recycling programmes. It is said that the plastic bags take between 20 and 1,000 years to degrade fully in the environment (Parliament of New South Wales, 2004). The plastic wastes in the environment resulting into various impacts i.e., useful materials sheltered in the landfills become wasted resources; water bodies and landscapes turn ugly and unhygienic; fear to wildlife; and open burning emits toxic gas (Zero Waste New Zealand, 2002).

The plastic wastes, thrown on the sides of road, open areas, riverbanks, in drainage canals, and common places resulted in death and health problems of cattle. Besides, the intake of plastic items resulted in the reduction of yield of milk (Ramasamy and Sharma, 2011). The 2003 International Coastal Cleanup says that the plastic wastes have become a serious threat to the aquatic life. The plastic bag waste holds second and third positions in India and South Africa respectively as one of the items in the marine debris (ICC, 2003).

The nuisance of plastic waste has many root causes in Nairobi. The production and consumption as externality is the prime one. This means that nobody is paying for the undesirable impacts on the environment caused by the plastic waste. There are no collection and disposal costs included in the materials' product cost. Hence, plastic bags have become cheaper and overly used, by the way leading to the throw away consumerism. In addition to that low level of awareness among public on the disposal of 
wastes is also an important factor. Recycling of plastic bags becomes difficult due to the co-disposal of plastic bags (Girum Bahri, 2005). Even though the plastic bags have good things on functional and environmental aspects, the carefree means of production and consumption have become an important issue today. People consume trillions of plastic bags, and after use they end up in litter stream. Almost all the countries at global level (for instance, India, South Africa, Australia and Ireland) have realised the intensity of the environmental impact of plastic wastes to take strategic measures (Girum Bahri, 2005).

\section{OBJECTIVES}

The present study attempts to understand the ground reality through the following objectives.

- To assess the level of environmental concern of the public.

- To measure the intensity of attitude of the public towards disposal of plastic wastes.

- To ascertain the mode of disposal of plastic wastes by the public.

\section{MATERIALS AND METHODS}

\section{Area of the Study}

Data for this study was collected in Tiruchirapalli City Corporation of Tamilnadu. Tiruchirapalli City was selected as the area of study as it is one of the fast growing cities in Tamilnadu as well as in India, with a number of industrial units and commercial activities. It is also one of the leading municipal corporations in Tamilnadu registering higher rate of urban growth, thus serving an ideal location for conducting the present study.

\section{Sampling Design}

The study is conducted in Tiruchirapalli Municipal Corporation area which is divided into four zones viz., Ponmalai, Ariyamangalam, Srirangam, and K. Abhisegapuram for administrative purpose. Each zone comprises 15 wards. Thus, Tiruchirapalli City Corporation comprises 60 wards. For the present study from each zone one ward was selected randomlyfrom Srirangam zone ward number12; from Ariyamangalam zone ward number 14; from Ponmalai zone ward number 34; and K. Abishekapuram zone ward number 53. From each ward households were selected at random as units of study at the rate of 5 per cent. The sampling method adopted for the study is multistage sampling method. The tools interview schedule supplemented by observation used for the collection of primary data.

Table 1: Sample design

\begin{tabular}{|c|c|c|c|}
\hline Name of the Zone & Ward's Number & No. of Households & Size of Sample \\
\hline Srirangam & 12 & 2636 & 132 \\
\hline Ariyamangalam & 14 & 2497 & 125 \\
\hline Golden Rock & 34 & 2555 & 128 \\
\hline K.Abishekapuram & 53 & 2594 & 130 \\
\hline \multicolumn{3}{|c|}{ Total } & 515 \\
\hline
\end{tabular}

\section{Secondary Data}

The Documents, Reports, and Records available in the Tiruchirappalli Municipal Corporation Administration, District Pollution Control Office, Tamilnadu Water supply and Drainage Tiruchirappalli Branch Office, and Public Health Department are the main sources of the Pre-data needed for the study. 


\section{RESULTS AND Discussions}

The data reveal that the respondents fell in three economic (income) classes, viz., low, middle and high. Based upon the average $(1,97,571.26)$ and standard deviation $(1,22,609.66)$, those who have the annual income of Rs. 75,000 and below fall in low income group; those who have annual income of Rs. 3,20,000 constitute high income group; and those who have the annual income ranging from 75,000 to 3,20,000 constitute middle income group. Of the total respondents 47.8 per cent fall in low income group; 27.2 per cent middle income group; and 25.0 per cent the high income group.

Table 2: Annual Family Income of the Respondents

\begin{tabular}{|l|c|c|}
\hline Annual Family Income & No. of Respondents & Per cent \\
\hline Low Income (<Rs. 75,000) & 246 & 47.8 \\
\hline Middle Income (Rs. 75,000 to Rs. 3,20,000) & 140 & 27.2 \\
\hline High Income (>Rs. 3,20,000) & 129 & 25.0 \\
\hline Total & 515 & 100 \\
\hline
\end{tabular}

The data show that invariably all income groups use plastic materials at least a couple of times. After using the plastic materials sufficiently, they become a waste, and such wastes find their way towards disposal.

The disposal pattern of the respondents appears to be related to their attitude. By using the scaling technique, the attitude of the respondents was quantitatively measured. The data analysis for the calculation of average score (44.95) and Standard deviation (10.77) yields three levels of attitude, viz., low (34 and below (i.e., average - Standard deviation), high (55 and above (i.e., average + Standard deviation) and moderate (between 34 and 55 (i.e., the scores between low and high). The three levels of attitude are distributed in the three income groups as shown in the following table.

Table 3: Annual Family Income and Attitude towards Disposal of Plastic Wastes of the Respondents

\begin{tabular}{|l|c|c|c|c|}
\hline \multirow{2}{*}{ Annual Family Income } & \multicolumn{2}{|c|}{ Attitude towards Disposal of plastic wastes } & \multirow{2}{*}{ Total } \\
\cline { 2 - 4 } & Low & Medium & High & \\
\hline Low & $95(38.6 \%)$ & $85(34.6 \%)$ & $66(26.8 \%)$ & 246 \\
\hline Middle & $40(28.6 \%)$ & $61(43.6 \%)$ & $39(27.9 \%)$ & 140 \\
\hline High & $30(23.3 \%)$ & $47(36.4 \%)$ & $52(40.3 \%)$ & 129 \\
\hline Total & $165(32.0 \%)$ & $193(37.5 \%)$ & $157(30.5 \%)$ & $515(100.0 \%)$ \\
\hline
\end{tabular}

The table above illustrates that the low-income group has the low level of attitude; the middle-income group, the moderate level of attitude; and high-income group, the high level of attitude. Thus, there seems to be a significant difference in the levels of attitude towards disposal among the three income groups. The difference is statistically significant in the application of the chi-square test.

Table 4: Chi-Square Test- Annual Family Income and Attitude towards Disposal of Plastic Wastes

\begin{tabular}{|l|c|c|c|}
\hline & Value & Df. & Asymp. Sig. (2 Sided) \\
\hline Pearson Chi-Square & $14.421^{\mathrm{a}}$ & 4 & .006 \\
\hline Likelihood Ratio & 14.187 & 4 & .007 \\
\hline No. of valid cases & 515 & & \\
\hline
\end{tabular}


Table 5: Annual Family Income and Mode of Disposal of Plastic Wastes

\begin{tabular}{|l|c|c|c|c|}
\hline \multirow{2}{*}{$\begin{array}{l}\text { Annual } \\
\text { Family } \\
\text { Income }\end{array}$} & \multicolumn{2}{|c|}{ Mode of Disposal of plastic wastes } & \multirow{2}{*}{ Total } \\
\cline { 2 - 4 } & $\begin{array}{c}\text { Throwing in the } \\
\text { open space }\end{array}$ & $\begin{array}{c}\text { Dumping in } \\
\text { the Waste bin }\end{array}$ & Others & \\
\hline Low & $122(49.6 \%)$ & $110(44.7 \%)$ & $14(5.7 \%)$ & 246 \\
\hline Middle & $65(46.4 \%)$ & $61(43.6 \%)$ & $14(10.0 \%)$ & 140 \\
\hline High & $35(27.1 \%)$ & $83(64.3 \%)$ & $11(8.5 \%)$ & 129 \\
\hline Total & $222(43.1 \%)$ & $254(49.3 \%)$ & $39(7.6 \%)$ & $515(100.0 \%)$ \\
\hline
\end{tabular}

The attitude is reflected in the mode of disposal of plastic wastes. In the case of those having low level of attitude towards disposal, the disposal pattern is not environmental friendly. It is the low-income group that has predominantly the low level of attitude has such environment unfriendly mode of disposal. They throw away the plastic wastes mostly in the open space. The middle income group, even though they have moderate level of attitude, also throw away the plastic wastes mostly in the open space. The highincome group which has the high level of attitude towards disposal, dispose of plastic wastes in the environment-friendly manner. They put the plastic wastes in the waste bins provided by the corporation. The data show that 64.3 percentage of the respondents of the high income group throw the plastic wastes in the waste bins, as against 47.6 percentage in the middle income group and 44.7 percentage in the low income group. Thus, there exists a difference in the mode of disposal of plastic wastes between the three income groups. The chi-square demonstrates that the difference is statistically significant.

Table 6: Chi-Square Test- Annual Family Income and Mode of Disposal of Plastic Wastes

\begin{tabular}{|l|l|l|l|}
\hline & Value & Df. & Asymp. Sig. (2 Sided) \\
\hline Pearson Chi-Square & $20.688^{\mathrm{a}}$ & 4 & .000 \\
\hline Likelihood Ratio & 21.292 & 4 & .000 \\
\hline No. of valid cases & 515 & & \\
\hline
\end{tabular}

The mode of disposal of the respondents reflects the extent of their concern over the environment and need its improvement. The data show that the respondents have varying levels of concern over the environment and that their economic condition (Annual income level) has a bearing on the level of environmental concern. As per the data there are three levels of environmental concern as measured in terms of the average (40.44) and Standard deviation (10.80) of the scores obtained on the scale seeking to measure the concern. The score of 29 and below (average of 40.44-Standard deviation 10.80) signifies low level of environmental concern; the score of 51 and above (average of 40.44+ standard deviation of 10.80), high level of environmental concern; and the score of between 29 and 51, moderate level of environmental concern.

Table 7: Annual Family Income and Environmental Concern

\begin{tabular}{|l|c|c|c|c|}
\hline \multirow{2}{*}{$\begin{array}{l}\text { Annual Family } \\
\text { Income }\end{array}$} & \multicolumn{2}{|c|}{ Environmental Concern } & \multirow{2}{*}{ Total } \\
\cline { 2 - 4 } & Low & Medium & High & \\
\hline Low & $113(45.9 \%)$ & $102(41.5 \%)$ & $31(12.6 \%)$ & 246 \\
\hline Middle & $58(41.4 \%)$ & $63(45.0 \%)$ & $19(13.6 \%)$ & 140 \\
\hline High & $31(24.0 \%)$ & $73(56.6 \%)$ & $25(19.4 \%)$ & 129 \\
\hline Total & $202(39.2 \%)$ & $238(46.2 \%)$ & $75(14.6 \%)$ & $515(100.0 \%)$ \\
\hline
\end{tabular}


The low income group is found to have mostly low level of environmental concern; the middle and high income groups are found to have mostly moderate level of environmental concern each. The chi-square test confirms that the distance of difference between the three income groups in environmental concern and notifies it to be statistically significant. However, the table number 7 indicates that the high and middle-income groups come together in having a higher frequency percentage of moderate environmental concern. It appears to be so. Indeed on the application of the chi-square test it seems that there is a statistically significant difference between the high and middle-income groups in environmental concern.

Table 8: Chi-Square Test- Annual Family Income and Environmental Awareness

\begin{tabular}{|l|c|c|c|}
\hline & Value & Df. & Asymp. Sig. (2 Sided) \\
\hline Pearson Chi-Square & $17.640^{\mathrm{a}}$ & 4 & .001 \\
\hline Likelihood Ratio & 18.398 & 4 & .001 \\
\hline No. of valid cases & 515 & & \\
\hline
\end{tabular}

Table 9: Chi-Square Test- Middle and High Income vs Environmental Awareness

\begin{tabular}{|l|c|c|c|}
\hline & Value & Df. & Asymp. Sig. (2 Sided) \\
\hline Pearson Chi-Square & $9.310^{\mathrm{a}}$ & 2 & .010 \\
\hline Likelihood Ratio & 9.428 & 2 & .009 \\
\hline Linear-by-Linear Association & 7.722 & 1 & .005 \\
\hline No. of valid cases & 269 & & \\
\hline
\end{tabular}

The statistically significant difference between high and middle-income groups in environmental concern is due to the fact that the moderate level of environmental concern is more pronounced in high income group than in middle income group as shown by the frequency in the table number 7.

\section{CONCLUSION}

Thus the study shows that the economic status i.e., income level has a bearing on the usage and disposal of plastic materials. The low income group stands low in attitude towards disposal and environmental concern. They dispose the plastic wastes in the open area in such a way as to cause environmental degradation. The observation points to the need for shaping the attitudes of the low group people towards the proper disposal of plastic wastes and creating environmental concern among them so that the environment will remain graded and clean.

\section{REFERENCES}

Chintan, (2010) Plastics: A Threat to Mankind, National Book Trust, New Delhi, India.

Girum Bahri, (2005), Sustainable Management of Plastic Bag Waste: The Case of Nairobi, Kenya, Lund, Sweden.

Heynen, N, (2003), “The scalar production of injustice within the urban forest", Antipode, 35 (5), 980-998.

Hussain M and Mushtaq MM. 2014. Awareness about Hospital Wastes and its effects on the Health of Patients in District Dera Ghazi Khan. Asian Journal of Applied Science and Engineering, 3, 41-48.

India Business, (2013), Plastic per capita consumption to double in 5 years, The Times of India.

International Coastal Cleanup. (2003) South Africa summary report. [Online]. Available from http://www.coastalcleanup.org/documents/CountrySummaries/2003_ICC_Summary_SouthA frica.pdf [Accessed: 5th May2005].

Owino FO, Hayombe PO and Agong SG. 2014. Spatial Planning Interventions and their Implications on Conservation of Urban Green Spaces. Asian Journal of Applied Science and Engineering, 3, 61-72. 
Parliament of New South Wales. (2004), Briefing paper no. 5/2004 by Stewart Smith. [Online]. Available from http://www.parliament.nsw.gov.au/pro/parlment/publications.nsf/0/33469EB37225F1F8CA256E CF0007 7497. [Accessed: 20 th July 2005].

Plastics News, (2013), Study: Plastic consumption to double in India by 2016. [Online]. Available from http://www.plasticsnews.com/article/20131204/NEWS/131209962/study-plasticconsumption-to-double-in-india-by-2016.

Ramasamy, V. \& Sharma, HR. (2011) Plastic bags - threat to environment and cattle health: A retrospective study from the Gondar city of Ethiopia. The Official J. Inst. Integr. Omics Appl. Biotech. J. 2(1). p. 7-12, 2011.

Tavili RH, Javadi SA. Classification and Determination of Indicator Environmental Properties in Western Iran Rangelands. Asia Pacific Journal of Energy and Environment. 2014;1(1):39-44.

Yaqob EY, Al-Sa`ed R, Sorial G and Sudian M. 2014. Situation Analysis and Perspectives of Transboundary Waste Water Management Along Israel/palestine borders. Asian Journal of Applied Science and Engineering, 3, 82-95.

Zero Waste New Zealand. (2002) Plastic shopping bag report. [Online]. Available from http://www.zerowaste.co.nz/assets/Reports/PlasticShoppingBagsandbiodegradablepackagin g.pdf [Accessed: 6th march 2005]. 
Publish Online and Print Version Both

Issue Link URL: http://hdl.handle.net/20.500.11903/jar.v4n1

ISSN Online: 2312-203X 